\title{
Financial problems associated with food insecurity among public university students in Peninsular Malaysia
}

\author{
Nurulhudha Mohd Jamil ${ }^{1}$, Norhasmah Sulaiman ${ }^{1,2^{*}}$, Siti Nur'Asyura Adznam ${ }^{3,4}$ \\ \& Shamsul Azahari Zainal Badari ${ }^{5}$
}

${ }^{1}$ Department of Nutrition, Faculty of Medicine and Health Sciences, Universiti Putra Malaysia, 43400, Serdang, Selangor; ${ }^{2}$ Research Centre of Excellence for Nutrition and Non-Communicable Disease, Faculty of Medicine and Health Sciences, Universiti Putra Malaysia, 43400, Serdang, Selangor; ${ }^{3}$ Department of Dietetics, Faculty of Medicine and Health Sciences, Universiti Putra Malaysia, 43400, Serdang, Selangor; ${ }^{4}$ Malaysian Research Institute on Aging (MyAging), Universiti Putra Malaysia; ${ }^{5}$ Department of Resource Management and Consumer Studies, Faculty of Human Ecology, Universiti Putra Malaysia, 43400 UPM Serdang, Selangor

\begin{abstract}
Introduction: Food is a necessity for students. Yet, students' food expenditure is anticipated to be restrained by their financial status. This cross-sectional study aims to determine the prevalence of food insecurity and its determinants among university students attending public universities in Peninsular Malaysia. Methods: Multistage random sampling was used to select respondents from public universities in Peninsular Malaysia. A total of 427 undergraduate students completed a selfadministered questionnaire at four randomly selected universities (Universiti Utara Malaysia, Universiti Kebangsaan Malaysia, Universiti Malaysia Pahang and Universiti Teknologi Malaysia). The questionnaire consisted of information concerning demographic and socioeconomic backgrounds, food security status, eating behaviour, financial literacy, and financial problem among university students. Frequency, chi-square, and logistic regression were used to analyse the variables. Results: Mean age of the respondents was 21.6 years, and $60.9 \%$ were found to be food insecure. Gender $\left(\chi^{2}=5.415\right)$, origin $\left(\chi^{2}=3.871\right)$, number of siblings $\left(\chi^{2}=4.521\right)$, financial problem $\left(\chi^{2}=42.364\right)$, and regular breakfast intake $\left(\chi^{2}=5.654\right)$ were associated with food security status $(p<0.05)$. Male respondents had 1.5 times (AOR=1.547, 95\% CI: 1.006-2.380) the risk of having low food security status. Those with higher financial problems (AOR=3.575, 95\% CI: 2.332-5.481) were 3.5 times more likely to be food insecure. Conclusion: The prevalence of food insecurity among public university students in Peninsular Malaysia was significantly high. Thus, intervention studies should focus on students with financial problems. Moreover, establishing a better system for an on campus food pantry or food bank is needed to counter the high prevalence of food insecurity among university students.
\end{abstract}

Keywords: Food insecurity, financial literacy, financial problem, meal skipping, university students

\footnotetext{
*Corresponding author: Assoc. Prof. Dr. Norhasmah Sulaiman

Department of Nutrition, Faculty of Medicine and Health Sciences, Universiti Putra Malaysia, 43400, Serdang, Selangor

Tel: (6)(03) 9769 2461; Fax: (6)(03) 9769 2458; E-mail: norhasmah@upm.edu.my

doi: https://doi.org/10.31246/mjn-2020-0032
} 


\section{INTRODUCTION}

Obtaining sufficient food is a fundamental human right. As stated in the Universal Declaration of Human Rights, Article 25: food and shelter are for all (OHCHR, 1948). Everyone has the right to a standard of living adequate for health and well-being, including food. Food is a vital necessity of life. However, more than 800 million people in developing countries are not getting enough of it (WFP, 2020).

Food security is known as a significant concern at the individual, household, national, regional, and worldwide level. Food security exists when people can acquire safe, nutritionally adequate, and culturally acceptable foods at all times in a manner that maintains human dignity (FAO, 2008). On the other hand, food insecurity was initially defined in 1990 by Life Sciences Research Office (LSRO, 1990). It stated that food insecurity happens when the food systems are stressed, causing food to be not accessible, available, and enough quality, or the ability to acquire acceptable food in a socially acceptable way is limited or uncertain.

Published studies have addressed the high prevalence of food insecurity among university and college students. Based on a systematic review done by Bruening et al. (2017), the prevalence of food insecurity among the students ranged from $14.1 \%$ to $58.8 \%$ in the United States, $46.5 \%$ to $47.6 \%$ in Australia, $82.8 \%$ in Canada, and $12.5 \%$ to $84.0 \%$ in South Africa. Meanwhile, in Malaysia, the prevalence of food insecurity among university students ranges from $43.5 \%$ to 67.1\% (Norhasmah, Zuroni \& Marhana, 2013; Nur Atiqah et al., 2015; Wan Azdie et al., 2019), which is at an alarming rate. Combating food insecurity is real, getting enough and healthy food is a struggle.
A study was done by Norhasmah et al. (2013), focusing on the coping strategies and consequences of food insecurity among university students in four public universities namely, University Malaysia Perlis (UNIMAP), Universiti Malaya (UM), Universiti Teknikal Malaysia Melaka (UTeM), and University Sultan Zainal Abidin (UNiSZA). It also reported on the correlation between expenditure and food security status among students. Nur Atiqah et al. (2015) stated the consequences of food insecurity, focusing on its association with lipid profile among university students in Universiti Teknologi MARA (UiTM) Puncak Alam, while Wan Azdie et al. (2019) studied the determinants of food insecurity, focusing on the demographics, spending patterns, living arrangements, and time constraints among university students in International Islamic University Malaysia (IIUM), Kuantan. All these three studies were done in public universities within Peninsular Malaysia, focused on the prevalence of food insecurity among university students. Yet, none of these studies focused on financial literacy, financial problem, and eating behaviour as determinants of food insecurity among university students across Peninsular Malaysia. Among university students, food insecurity is consistently associated with financial independence, therefore they are required to start managing their money at this instance (Bruening et al., 2017). According to Mohamad Fazli et al. (2008), university students are not prepared to manage their money on campus when they enroll into university. Students with food insecurity are significantly associated with those who are renting, boarding or sharing accommodation, having low incomes or are receiving government financial assistance (Hughes et al., 2011; Norhasmah et al., 2013). 
According to Mohamad Fazli \& MacDonald (2010), financial literacy among university students was defined based on their knowledge regarding financial goals, financial records, savings, investments, retirement, banking system, time value of money, wills, insurance, education loan, and general knowledge on personal finance. The study also stated that university students with better financial literacy were less likely to report having financial problems. Hogarth \& Hilgert (2002) also reported that university students aged between 18 to 24 years were those with the least financial literacy compared to other age groups. Low financial literacy eventually leads to financial problems (Md Hafizi, 2013). To cope with financial problems, university students have reportedly reduced their meal sizes or skipped meals altogether throughout an entire day (Hanna, 2014). Food security status can be influenced by several factors, such as lack of food and money management skills, including budget planning and expenditure management skills, which arise from having low financial literacy. A more detailed and wide study is needed to provide an in-depth explanation on the patterns of prevalence and determinants of food insecurity among university students in Peninsular Malaysia. Thus, this study aims to identify the prevalence and determinants (demographics and socioeconomic characteristics, financial literacy, financial problem and the eating behaviour) of food insecurity among public university students in Peninsular Malaysia.

\section{METHODOLOGY}

\section{Study design and samples}

A cross-sectional study was conducted in public universities located in Peninsular Malaysia. Data collection was done throughout semester two (April-May
2015/2016). Prior to data collection, permission to carry out the study was obtained from the selected universities. Multistage random sampling was employed for recruitments. All 18 public universities were categorised into four zones, that were northern, east coast, central, and southern zones. One university was randomly selected to represent each of the four zones, which were Universiti Utara Malaysia (UUM) for northern, Universiti Malaysia Pahang (UMP) in the east coast, Universiti Kebangsaan Malaysia (UKM) for central and Universiti Teknologi Malaysia (UTM) in the southern zone, respectively. Then, one faculty was randomly chosen to represent each university, followed by a random selection of two programmes in each faculty. Finally, respondents aged between 19 to 25 years old from each faculty were selected using random systematic sampling based on odd number sequence of a name list provided by the university. All respondents were Malaysian undergraduate students. Undergraduate students were chosen as respondents because they are at the age of transitioning from parental supervision to independent living and developing their own food patterns.

Ethical clearance was obtained from the Ethics Committee for Research Involving Human Subject (JKEUPM) of Universiti Putra Malaysia [Reference No: FPSK(EXP16) P071]. The permission to carry out the study within the university campus was granted by each of these universities. Written informed consent was obtained from all respondents.

\section{Measurements}

The survey was conducted using a structured questionnaire to obtain information on the demographics and socioeconomic characteristics, food security status, eating behaviour, financial literacy, and financial problem among the respondents. Food security 
status of university students was assessed during the past semester. The 10-item Adult Food Security Survey Module (USDA, 2012) was used to classify food security status among the respondents. Low food security and very low food security groups were merged into the food insecure category. All items were scored based on the Guide to Measuring Household Food Security and classified under the recommendations by USDA, Economic Research Service. Table 1 provides the definitions for each food security category and their corresponding scores.

Financial literacy was measured based on the total score of correct answers out of 25 questions concerning financial goals, financial records, savings, investments, retirement, banking system, time value of money, wills, insurance, education loan, and general knowledge of personal finance. This part consisted of 25 close-ended questions with true/false answers. One point was given to each correct response, thus, the total score was 25. This score was used to determine the level of financial literacy among students. This instrument has been developed and validated by Mohamad Fazli \& MacDonald (2010) based on the Malaysian context.
Meanwhile, financial problem was measured by using an instrument validated by Mohamad Fazli et al. (2008). Ten questions on financial problem were asked on a 5-point Likert scale ranging from never (1) to every day (5). The financial problem questions were focused on problems such as: uncertain about where the money is spent; owe friend(s) money; spend more than can afford; borrow money to buy food; skip meals to save money; take money without permission from parents/others; upset when cannot buy things; shopping to relieve tension/ stress; impulsive shopping, and lending money to friends. The range in total scores for financial problems was from a low of zero to a high of 50 . The mean score for overall financial problem was used to determine the status of financial problems among university students in Peninsular Malaysia.

The eating behaviour questionnaire (EBQ) was used to assess the frequency of meal intake among the respondents. This EBQ was adopted from a study done in Malaysia (Chin \& Mohd Nasir, 2009). There were six items on how frequent the respondents consumed each meal daily (breakfast, morning snack, lunch, evening snack, dinner, and supper). It ranged from never (zero)

Table 1. Classification of food security status

\begin{tabular}{lcl}
\hline Food security status & Cumulative response score & \multicolumn{1}{c}{ USDA definition } \\
\hline High food security & 0 & $\begin{array}{l}\text { No food access problems or } \\
\text { limitations }\end{array}$ \\
Marginal food security & 1 to 2 & $\begin{array}{l}\text { Anxiety over food sufficiency or } \\
\text { shortage of food in the house, with } \\
\text { little or no indication of changes in } \\
\text { food intake }\end{array}$ \\
Low food security & 3 to 5 & $\begin{array}{l}\text { Reduced quality, variety or } \\
\text { desirability of diet }\end{array}$ \\
Very low food security & $>5$ & $\begin{array}{l}\text { Disrupted eating patterns and } \\
\text { reduced food intake }\end{array}$ \\
\hline
\end{tabular}

Source: USDA (2012) 
to every day (seven times) a week. This study categorised the frequency of meal intakes into two categories: 'frequently skipped' with intakes less than five days per week for each meal, and 'regular intake' for intakes of five to seven days per week.

\section{Statistical analysis}

All data obtained were analysed using IBM SPSS version 23.0. All variables were presented as descriptive statistics that included frequency, percentage, mean, and standard deviation (SD). Chi-square was used to assess the association between all categorical variables with food security status. Binary logistic regression was used to determine the factors associated with food security status among respondents. Covariates were based on bivariate analysis, whereby only those with $p$-value of $<0.05$ were included in the adjusted model. The significance level of the analysis was based on a $p$-value of $<0.05$.

\section{RESULTS}

Distribution of the respondents' demographics and socioeconomic characteristics, financial literacy, financial problem, and eating behaviour are presented in Table 2. A total of 427 respondents from selected universities, namely UUM (Sintok), UMP (Gambang), UKM (Bangi), and UTM (Skudai) participated in this study with a $100 \%$ response rate. More than half of the respondents $(60.2 \%)$ were female students, in line with the current situation at public universities in Malaysia, which are monopolised by female students (MOE Malaysia, 2013).

Majority of the respondents were of Malay ethnicity (83.6\%), followed by Chinese $(6.2 \%)$, Indian $(4.7 \%)$, and others that included Bumiputera Sabah/ Sarawak and mixed (3.0\%). The age of all respondents ranged from
19 to 25 years old. The mean age was $21.56 \pm 1.35$ years old, with more than half of the respondents aged 19-21 years (males $51.2 \%$ and females $56.4 \%$ ). One third of the respondents $(39.8 \%)$ were in their first year of study $(36.5 \%$ males and $42.0 \%$ females), followed by second year $(25.8 \%)(21.8 \%$ males and $28.4 \%$ females), third year (24.4\%) $(26.5 \%$ males and $23.0 \%$ females), and a few in their final year (10.0\%) (15.3\% males and 6.6\% females). Public universities in Malaysia offer comfortable accommodations to the students, thus, most of the respondents $(96.5 \%)$ were staying on campus $(93.5 \%$ males and $98.4 \%$ females). Furthermore, all the respondents (100\%) were single. More than half of the respondents $(59.7 \%)$ originated from a rural area (55.3\% males and $62.7 \%$ females), while the rest were from an urban area (40.3\%) (44.7\% males and $37.4 \%$ females). The mean number of sibling(s) among respondents was $4.66 \pm 2.19$. Only a few respondents $(8.0 \%)$ were working as a part-timer $(10.0 \%$ males and $6.6 \%$ females). Based on family background, majority of the respondents (83.4\%) were from the household income category of Bottom $40 \%$ (B40) group $(78.2 \%$ males and $86.8 \%$ females), $12.2 \%$ from the Middle 40\% (M40) group (15.9\% males and $9.7 \%$ females) and $<5.0 \%$ from the Top 20\% (T20) group (5.9\% males and $3.5 \%$ females) (DOS Malaysia, 2017).

Female respondents (50.6\%) had a higher financial literacy compared to male respondents $(47.6 \%)$. At the same time, female respondents (56.0\%) reported having lower financial problems compared to males $(46.5 \%)$. Breakfast was the most skipped meal among the respondents (63.2\%). However, female respondents tended to skip breakfast more (63.4\%) compared to male respondents (53.5\%). Contrarily, both genders frequently took lunch $(80.3 \%)$ and dinner $(72.4 \%)$. Male respondents consumed food regularly $(81.8 \%$ for 
Table 2. Background of the respondents $(N=427)$

\begin{tabular}{|c|c|c|c|c|}
\hline \multirow{2}{*}{ Characteristics } & \multicolumn{3}{|c|}{$n(\%)$} & \multirow{2}{*}{$M e a n \pm S D$} \\
\hline & Male $(n=170)$ & Female $(n=257)$ & Total & \\
\hline \multicolumn{5}{|l|}{ University } \\
\hline UUM & $32(18.8)$ & $75(29.2)$ & $107(25.1)$ & \\
\hline UMP & $37(21.8)$ & $71(27.6)$ & $108(25.3)$ & \\
\hline UKM & $37(21.8)$ & 69 (26.9) & $106(24.8)$ & \\
\hline UTM & $64(37.7)$ & $42(16.3)$ & $106(24.8)$ & \\
\hline \multicolumn{5}{|l|}{ Ethnicity } \\
\hline Malay & $136(80.0)$ & $221(86.0)$ & 357 (83.6) & \\
\hline Chinese & $16(9.4)$ & $16(6.2)$ & $32(7.5)$ & \\
\hline Indian & $13(7.7)$ & $12(4.7)$ & $25(5.9)$ & \\
\hline $\begin{array}{l}\text { Bumiputra Sabah/ } \\
\text { Sarawak/Mixed }\end{array}$ & $5(2.9)$ & $8(3.1)$ & $13(3.0)$ & \\
\hline \multicolumn{5}{|l|}{ Age (years) } \\
\hline $19-21$ & $87(51.2)$ & $145(56.4)$ & $232(54.3)$ & $21.6 \pm 1.4$ \\
\hline $22-25$ & $83(48.8)$ & $112(43.6)$ & $195(45.7)$ & \\
\hline \multicolumn{5}{|l|}{ Years of study } \\
\hline $1^{\text {st }}$ & $62(36.5)$ & $108(42.0)$ & $170(39.8)$ & \\
\hline $2^{\text {nd }}$ & $37(21.8)$ & $73(28.4)$ & $110(25.8)$ & \\
\hline $3^{\text {rd }}$ & $45(26.5)$ & $59(23.0)$ & $104(24.4)$ & \\
\hline $4^{\text {th }}$ & $26(15.3)$ & $17(6.6)$ & $43(10.1)$ & \\
\hline \multicolumn{5}{|l|}{ Residence } \\
\hline In campus & $159(93.5)$ & $253(98.4)$ & $412(96.5)$ & \\
\hline Out campus & $11(6.5)$ & $4(1.6)$ & $15(3.5)$ & \\
\hline \multicolumn{5}{|l|}{ Origin $^{\dagger}$} \\
\hline Rural & $94(55.3)$ & $161(62.7)$ & $255(59.7)$ & \\
\hline Urban & $76(44.7)$ & $96(37.4)$ & $172(40.3)$ & \\
\hline \multicolumn{5}{|l|}{ Number of siblings } \\
\hline $1-3$ & $61(35.9)$ & $77(30.0)$ & $138(32.3)$ & $4.7 \pm 2.2$ \\
\hline $4-6$ & $71(41.8)$ & $157(61.1)$ & $228(53.4)$ & \\
\hline$>6$ & $38(22.4)$ & $23(9.0)$ & $61(14.3)$ & \\
\hline \multicolumn{5}{|l|}{ Working part-time } \\
\hline Yes & $17(10.0)$ & $17(6.6)$ & $34(8.0)$ & \\
\hline No & $153(90.0)$ & $240(93.4)$ & $393(92.0)$ & \\
\hline \multicolumn{5}{|l|}{ Household income } \\
\hline B40 (<RM 4360) & $133(78.2)$ & $223(86.8)$ & $356(83.4)$ & $3444.3 \pm 3979.4$ \\
\hline M40 (RM 4360- 9619) & $27(15.9)$ & $25(9.7)$ & $52(12.2)$ & \\
\hline T20 ( $\geq$ RM 9620) & $10(5.9)$ & $9(3.5)$ & $19(4.5)$ & \\
\hline \multicolumn{5}{|l|}{ Financial literacy } \\
\hline Lower than median & $89(52.4)$ & $127(49.4)$ & $216(50.6)$ & \\
\hline Higher than median & $81(47.6)$ & $130(50.6)$ & $211(49.4)$ & \\
\hline \multicolumn{5}{|l|}{ Financial problem } \\
\hline Lower than mean & $79(46.5)$ & $144(56.0)$ & $223(52.2)$ & $24.5 \pm 5.3$ \\
\hline Higher than mean & $91(53.5)$ & $113(44.0)$ & $204(47.8)$ & \\
\hline
\end{tabular}


Table 2. Background of the respondents $(N=427)$ [Cont'd]

\begin{tabular}{|c|c|c|c|c|}
\hline \multirow{2}{*}{ Characteristics } & \multicolumn{3}{|c|}{$n(\%)$} & \multirow{2}{*}{ Mean $\pm S D$} \\
\hline & Male $(n=170)$ & Female $(n=257)$ & Total & \\
\hline \multicolumn{5}{|l|}{ Eating behaviour } \\
\hline \multicolumn{5}{|l|}{ Breakfast } \\
\hline Frequently skipped & 107 (62.9) & $163(63.4)$ & $270(63.2)$ & \\
\hline Regular intake & $63(37.1)$ & $94(36.6)$ & $157(36.8)$ & \\
\hline \multicolumn{5}{|l|}{ Lunch } \\
\hline Frequently skipped & $31(18.2)$ & 53 (20.6) & $84(19.7)$ & \\
\hline Regular intake & $139(81.8)$ & $204(79.4)$ & $343(80.3)$ & \\
\hline \multicolumn{5}{|l|}{ Dinner } \\
\hline Frequently skipped & $29(17.1)$ & 89 (34.6) & $118(27.6)$ & \\
\hline Regular intake & $141(82.9)$ & $168(65.4)$ & $309(72.4)$ & \\
\hline \multicolumn{5}{|l|}{ Food security status } \\
\hline High food security & $15(8.83)$ & 27 (10.5) & $42(9.8)$ & \\
\hline Marginal food security & $40(23.5)$ & $85(33.1)$ & $125(29.3)$ & \\
\hline Low food security & 77 (45.3) & $91(35.4)$ & $168(39.3)$ & \\
\hline Very low food security & $38(22.4)$ & $54(21.0)$ & $92(21.6)$ & \\
\hline
\end{tabular}

${ }^{\top}$ Origin refers to the hometown of the respondents

${ }^{\star}$ Household Income and Basic Amenities (HIS/BA) survey of 2016

lunch and $82.9 \%$ for dinner) compared to female respondents $(79.4 \%$ for lunch and $65.4 \%$ for dinner). The prevalence of food insecurity was $60.9 \%$ among public university students in Malaysia, with $39.3 \%$ of them having low food security and $21.6 \%$ with very low food security (Table 2).

Table 3 shows that there were several significant associations $(p<0.05)$ between gender, origin, and the number of siblings with food security status. Females (67.1\%) were more food secured compared to males (32.9\%). Meanwhile, the origin from rural vs. urban $163.5 \%$ vs. $36.5 \%$ ), having $>4$ siblings vs. lesser (71.5\% vs. $28.5 \%)$, skipped breakfast frequently vs. regular breakfast intake $(58.5 \%$ vs. $41.5 \%)(p<0.05)$, and having high vs. low financial problem $(60.4 \%$ vs. $39.6 \%)(p<0.001)$ were significantly more prevalent among the food insecure respondents compared to the food secured respondents.
After controlling for covariates (Table 4), there were only two factors that significantly contributed to food security status. The model showed that according to gender, male respondents were 1.5 times more likely to suffer from food insecurity than females $(\mathrm{AOR}=1.547$, $95 \%$ CI: $1.006-2.380)(p<0.05)$, and respondents with higher financial problems had the highest odds of being 3.5 times more likely to experience food insecurity compared to those with low financial problems $(\mathrm{AOR}=3.575,95 \% \mathrm{CI}$ : 2.332-5.481) $(p<0.001)$.

\section{DISCUSSION}

There is a high prevalence of food insecurity (60.9\%) among university students in Peninsular Malaysia included in this study. Findings from this study are similar to previous studies done in Peninsular Malaysia (Norhasmah et al., 2013; Nur Atiqah et al., 2015; Wan Azdie et al., 2019). The trend of food 
Table 3. Association between factors and food security status among students $(N=427)$

\begin{tabular}{|c|c|c|c|c|}
\hline \multirow[t]{2}{*}{ Characteristics } & \multicolumn{2}{|c|}{$n(\%)$} & \multirow[t]{2}{*}{$\chi^{2}$} & \multirow[t]{2}{*}{$p$-value* } \\
\hline & Food secure & Food insecure & & \\
\hline \multicolumn{5}{|l|}{ University } \\
\hline UUM & $36(21.6)$ & $71(27.3)$ & 5.42 & 0.12 \\
\hline UMP & $36(21.6)$ & $72(27.7)$ & & \\
\hline UKM & 49 (29.3) & 57 (21.9) & & \\
\hline UTM & $46(27.5)$ & $60(23.1)$ & & \\
\hline \multicolumn{5}{|l|}{ Ethnicity } \\
\hline Malay & $132(79.0)$ & $225(86.8)$ & 5.46 & 0.14 \\
\hline Chinese & $18(10.8)$ & $14(5.4)$ & & \\
\hline Indian & $12(7.2)$ & $13(5.0)$ & & \\
\hline $\begin{array}{l}\text { Bumiputra Sabah/ } \\
\text { Sarawak/Mixed }\end{array}$ & $5(3.0)$ & $8(3.1)$ & & \\
\hline \multicolumn{5}{|l|}{ Gender } \\
\hline Male & 55 (32.9) & $115(44.2)$ & 5.42 & $0.02 *$ \\
\hline Female & $112(67.1)$ & $145(55.8)$ & & \\
\hline \multicolumn{5}{|l|}{ Age (years) } \\
\hline $19-21$ & $100(59.9)$ & $132(50.8)$ & 3.40 & 0.07 \\
\hline $22-25$ & $67(40.1)$ & $128(49.2)$ & & \\
\hline \multicolumn{5}{|l|}{ Years of study } \\
\hline $1^{\text {st }}$ & $69(41.3)$ & $101(38.9)$ & 0.84 & 0.84 \\
\hline $2^{\text {nd }}$ & $43(25.8)$ & $67(25.8)$ & & \\
\hline $3^{\text {rd }}$ & $37(22.2)$ & $67(25.8)$ & & \\
\hline $4^{\text {th }}$ & $18(10.8)$ & $25(9.6)$ & & \\
\hline \multicolumn{5}{|l|}{ Residence } \\
\hline In campus & $164(98.2)$ & $248(95.4)$ & 2.38 & 0.12 \\
\hline Out campus & $3(1.8)$ & $12(4.6)$ & & \\
\hline \multicolumn{5}{|l|}{ Origin $^{\dagger}$} \\
\hline Rural & 90 (53.9) & $165(63.5)$ & 3.87 & 0.05 \\
\hline Urban & $77(46.1)$ & $95(36.5)$ & & \\
\hline \multicolumn{5}{|l|}{ Number of siblings } \\
\hline $1-3$ & $64(38.3)$ & $74(28.5)$ & 4.52 & $0.03^{*}$ \\
\hline$\geq 4$ & $103(61.7)$ & $186(71.5)$ & & \\
\hline \multicolumn{5}{|l|}{ Working part-time } \\
\hline Yes & $9(5.4)$ & $25(9.6)$ & 2.48 & 0.12 \\
\hline No & $158(94.6)$ & $235(90.4)$ & & \\
\hline \multicolumn{5}{|l|}{ Household income ${ }^{\ddagger}$} \\
\hline B40 (< RM4360) & $131(78.4)$ & $225(86.5)$ & 4.93 & 0.09 \\
\hline M40 (RM 4360-9619) & $27(16.2)$ & $25(9.6)$ & & \\
\hline T20 ( $\geq$ RM9620) & $9(5.4)$ & $10(3.8)$ & & \\
\hline \multicolumn{5}{|l|}{ Financial literacy } \\
\hline Lower than median & $83(49.7)$ & $133(51.2)$ & 0.09 & 0.77 \\
\hline Higher than median & $84(50.3)$ & 127 (48.9) & & \\
\hline \multicolumn{5}{|l|}{ Financial problem } \\
\hline Lower than mean & $120(71.9)$ & $103(39.6)$ & 42.36 & $<0.01^{*}$ \\
\hline Higher than mean & $47(28.1)$ & $157(60.4)$ & & \\
\hline
\end{tabular}




\begin{tabular}{|c|c|c|c|c|}
\hline \multirow[t]{2}{*}{ Characteristics } & \multicolumn{2}{|c|}{$n(\%)$} & \multirow[t]{2}{*}{$\chi^{2}$} & \multirow[t]{2}{*}{ p-value* } \\
\hline & Food secure & Food insecure & & \\
\hline \multicolumn{5}{|l|}{ Eating behaviour } \\
\hline \multicolumn{5}{|l|}{ Breakfast } \\
\hline Frequently skipped & 89 (53.3) & $108(41.5)$ & 5.65 & $0.02 *$ \\
\hline Regular intake & $78(46.7)$ & $152(58.5)$ & & \\
\hline \multicolumn{5}{|l|}{ Lunch } \\
\hline Frequently skipped & $140(83.8)$ & $226(86.9)$ & 0.79 & 0.74 \\
\hline Regular intake & $27(16.2)$ & $34(13.1)$ & & \\
\hline \multicolumn{5}{|l|}{ Dinner } \\
\hline Frequently skipped & $130(78.3)$ & $208(80.0)$ & 0.18 & 0.68 \\
\hline Regular intake & $36(21.7)$ & $52(20.0)$ & & \\
\hline
\end{tabular}

${ }^{*} p$-value $<0.05$

'Origin refers to the hometown of the respondents

${ }^{\ddagger}$ Household Income and Basic Amenities (HIS/BA) survey of 2016

insecurity prevalence is seen to be more significant when multiple universities from different locations were involved, as shown by Norhasmah et al. (2013) at $67.1 \%$ compared to studies that only focused on one location, such as those done by Wan Azdie et al. (2019) at 54.4\% and Nur Atiqah et al. (2015) at 43.5\%, respectively. This is because of the mixture of urban and rural locations of the universities, which might influence food accessibility. For example, the high cost of food transportation from rural to urban areas. Food items in the university located in an urban area costs more compared to a rural area. Fresh food items such as vegetables and fish can also be one of the most expensive items in urban areas, given the costs acquired in their marketing, in

Table 4. Factors associated with food security status among students $(N=427)$

\begin{tabular}{|c|c|c|}
\hline Variable & Adjusted OR $(95 \%$ CI) & p-value \\
\hline \multicolumn{3}{|l|}{ Gender } \\
\hline Male & $1.55(1.01-2.38)$ & 0.05 \\
\hline Female & 1.00 (ref) & \\
\hline \multicolumn{3}{|l|}{ Origin } \\
\hline Rural & $1.38(0.90-2.12)$ & 0.14 \\
\hline Urban & 1.00 (ref) & \\
\hline \multicolumn{3}{|l|}{ Number of siblings } \\
\hline $1-3$ & 1.00 (ref) & \\
\hline$\geq 4$ & 0.99 (0.61-1.60) & 0.96 \\
\hline \multicolumn{3}{|l|}{ Financial Problem } \\
\hline Lower than median & 1.00 (ref) & \\
\hline Higher than median & $3.58(2.33-5.48)$ & $<0.01^{*}$ \\
\hline \multicolumn{3}{|l|}{ Eating Behaviour } \\
\hline \multicolumn{3}{|l|}{ Breakfast } \\
\hline Frequently skipped & $1.30(0.85-2.0)$ & 0.23 \\
\hline Regular intake & 1.00 (ref) & \\
\hline
\end{tabular}

${ }^{*} p$-value $<0.05$

${ }^{\dagger}$ Adjusted for gender, origin, number of siblings, financial problem, and breakfast intake 
terms of transportation from production areas, with some that perished during transportation process (Armar-Klemesu, 2000; Rose et al., 2008).

Even though there was a high percentage of food insecurity reported from the respondents that came from B40 families, there was no association between household income and food security status in this study (Table 3). On the contrary, as reported by Wan Azdie et al. (2019), respondents with parental income of more than RM 5000 were food secured (41.3\%). Despite the difference in food costs between these university locations, students get the same amount of funds from family members, education loan or scholarships, depending on their family's financial status. Wan Azdie and collegues (2019) also reported high food insecurity among respondents with Perbadanan Tabung Pendidikan Tinggi Nasional (PTPTN) loan compared to those on Jabatan Perkhidmatan Awam Malaysia (JPA) scholarship. A study conducted by Meldrum \& Willows (2006) reported that there was a relationship between higher food costs with the money received from financial aids. Healthy food costs more to the students with an economical diet, with lower financial aid. Thus, regardless of household income and types of scholarship, the lack of financial literacy and management will contribute to higher financial problems among students, which later leads to food insecurity.

Moreover, studies done by Thanthida (2010) stated that people, particularly those originating from rural areas with limited purchasing power, are more likely to be confronted by the problem of food insecurity. The basis of the problem most likely stems from poverty or a lowincome family. Hence, it explains how the origin is somehow associated with food insecurity status among university students. Respondents originating from rural areas who are enrolled in universities located in the urban areas with higher food costs to bear may face food insecurity due to lack of financial sources, management and literacy.

A bigger family and low-income households have been associated with prevalent food insecurity. Those having more than four siblings have a higher tendency to be food insecure, as supported by Costa et al. (2017). A study done by Nur Hafizah et al. (2013) stated that socio-economic level affects eating behaviour, in which students who come from lower or middle-income families spend less on food compared to those from high-income families.

This study documented a significant association between male students and food insecurity, even though male respondents spent more on food (Meldrum \& Willows, 2006). These findings are supported by studies done by Hughes et al., (2011). This was due to the spending behaviour among the students, in which, female students were more likely to create monthly savings and budgeting (Danek, 2017). In contrast, male students spent more on food. A study conducted by Hayhoe et al. (2000) stated that females spend more on clothing and appearance items, compared to males who spend on leisure items such as electronics, entertainment and food when they are away from home. The findings also showed that female students tended to cut their daily necessities and save regularly compared to male students.

Danek (2017) reported an association between female students with food insecurity. However, Hughes et al., (2011) reported that no association between gender and food insecurity among university students. Thus, both genders are exposed to food insecurity. Based on the report by Amare (2010), students tended to have a late breakfast or might combine it with lunch, or have an early dinner as a coping strategy by 
means of skipping meals. A review done by Pendergast et al. (2016) detailed that students tended to take late breakfast or combine breakfast with lunch as brunch because of time constraints, cost, and weight control, which is most prominent among female students.

This study also recorded that male students had low financial literacy and were reported to engage in high financial problems. Furthermore, respondents who were dealing with financial problems were almost thrice as likely to report experiences with food insecurity, suggesting that financial assistance was short of meeting their financial demands of attending university (Meldrum \& Willows, 2006; Norhasmah et al., 2013). Conversely, according to Mohamad Fazli et al. (2008), most students used education funding for purposes other than for academic expenses. This showed that there is less awareness on financial literacy and management among the students (Dahlia, Rabitah \& Zuraidah, 2009; Md Hafizi, 2013), indicating that students are somewhat unprepared in managing their money on campus. Prominent financial problem among students increases their risk of engaging with low food security status. Insufficient money was reported as the primary contributor to the prevalence of food insecurity among students (Hanna, 2014). Due to financial stress and as a strategy to cope with food insecurity, some tend to borrow money to buy food and might even buy on credit (Mohamad Fazli et al., 2008; Norhasmah et al., 2013).

Nevertheless, it is important to highlight that regardless of gender, students with financial problems were more likely to be food insecure. Since university students have more independence while living away from their family for the first time, they need to manage the demands of both financial and studies at the same time.
Furthermore, Darmon \& Drewnowski (2008) stated that the strategy of food insecure consumers in saving money is by selecting high energy-dense foods instead of nutrient-dense foods. These foods are low in nutritional quality and have a higher level of calories, which may contribute to overweight, obesity, and abdominal adiposity. With this alarming prevalence of food insecurity among university students, actions must be made before it becomes detrimental to their health and leads to negative impacts on their academic performances.

One of the limitations of this study was its cross-sectional study design. Thus, the causal relationship between the variables could not be traced. Other possible factors of food security status among university students in Peninsular Malaysia that focus on financial aspects should be covered in future studies.

\section{CONCLUSION}

A high prevalence of food insecurity $(60.9 \%)$ denotes that it is a major problem among the university students studied. This study revealed that every three out of five university students in Malaysia are food insecure. Gender and financial problem were the main factors contributing to food insecurity among public university students in Peninsular Malaysia. Intervention studies are essential to scale down the prevalence of food insecurity, such as by increasing food availability and accessibility on campus. Every public university in Malaysia should provide and establish food banks or pantry around the campus for students. Despite the fact that some of the universities have already implemented this, a proper system should be applied to make it work. Development studies focusing on food consumption and the cost of healthy foods should be conducted, providing the basis between the different needs 
of food for each gender, on whether to provide more food for males compared to female students, since males need more calories than females. At the same time, a better system to control food price on campus should be one of the efforts from the university authorities.

Other than that, an in-depth qualitative study can be done to unroot the issues of food insecurity among the students, focusing on financial issues. Intervention studies focusing on students with financial problems is a must. Moreover, there is a need to prepare students on how to properly manage their financial resources. University authorities, relevant policymakers, and professionals can also help by conducting talks to educate students on financial literacy in the early years of university enrolment. Increasing the education fund will also lessen the financial burden of the students.

\section{Acknowledgement}

The study was funded by the Malaysian Consumer and Family Economics Association (MACFEA) mini-grant 2016/2017. We wish to thank the universities' (UUM, UKM, UMP, and UTM) staffs and students who took part in the survey.

\section{Authors' contribution}

NMJ, collected and analysed the data, as well as wrote the manuscript; NS, supervised the flow of the research and reviewed the manuscript; SNA, reviewed the manuscript; SAZB, reviewed the manuscript.

\section{Conflict of interest}

All the authors declare no conflict of interests.

\section{References}

Amare Y (2010). Urban Food Insecurity and Coping Mechanisms. A Case Study of Lideta Sub-city in Addis Ababa. Forum for Social Studies (FSS) Research Report. Addis Ababa, Ethiopia. From http: / / publication.eiar.gov.et:8080/xmlui / bitstream/handle/123456789/3046/22. pdf 1 abbyy.pdf? sequence $=1 \&$ is Allowed $=y$ [Retrieved June 6 2019].
Armar-Klemesu M (2000). Growing Cities, Growing Food: Urban Agriculture on the Policy Agenda. A Reader on Urban Agriculture. In N Bakker, M Dubbeling, S Gündel, U Sabel-Koschella, $\& \mathrm{H}$ de Zeeuw (eds). Urban Agriculture and Food Security, Nutrition and Health (pp. 99117). Deutsche Stiftung fur Internationale Entwicklung (DSE), Zentralstelle fur Ernahrung und Landwirtschaft. Feldafing, Germany.

Bruening M, Argo K, Payne-Sturges D \& Laska MN (2017). The struggle is real: a systematic review of food insecurity on postsecondary education campuses. JAcad NutrDiet 117(11):1767-1791. https://doi.org/10.1016/j.jand.2017.05.022

Chin YS \& Mohd Nasir MT (2009). Eating behaviour among female adolescents in Kuantan District, Pahang, Malaysia. Pak J Nutr 8(4):425-432. https://doi.org/ 10.3923/pjn.2009.425.432

Costa NS, Santos MO, Carvalho CPO, Assunção ML \& Ferreira HS (2017). Prevalence and factors associated with food insecurity in the context of the economic crisis in Brazil. Current Developments in Nutrition 1(10). https://doi. org/10.3945/cdn.117.000869

Dahlia I, Rabitah H \& Zuraidah MI (2009). A study on financial literacy of Malaysian degree students. Cross-Cultural Communication 5(4):51-59.

Danek A (2017). Food Insecurity and Related Correlates among Students Attending Appalachian State University. Appalachian State University. Boone, North Carolina.

Darmon N \& Drewnowski A (2008). Does social class predict diet quality? $1-3$. Am J Clin Nutr 87:1107-1117.

DOS Malaysia (2017). Household Income and Basic Amenities Survey Report (HIS) 2016. Department of Statistics Malaysia. From https://newss.statistics.gov.my/newssportalx/ep/epFreeDownloadContentSearch. seam?cid=54306 [Retrieved November 23 2019].

FAO (2008). EC-FAO Food Security Information for Action Programme. Food and Agriculture Organization of the United Nations, Rome.

Hanna LA (2014). Evaluation of food insecurity among college students. Am Int $J$ Contemp Res $4(4): 46-49$.

Hayhoe CR, Leach LJ, Turner PR, Bruin MJ \& Lawrence FC. (2000). Differences in spending habits and credit use of college students. $J$ Consum Aff 34(1):113-133. 
Hogarth JM \& Hilgert MA (2002). Financial knowledge, experience and learning preferences: preliminary results from a new survey on financial literacy. Proceedings of the American Council on Consumer Interests 2002 Annual Conference. Consumer Interest Annual 48:1-7.

Hughes R, Serebryanikova I, Donaldson K \& Leveritt M (2011). Student food insecurity: The skeleton in the university closet. Nutr Diet 68(1):27-32. https://doi.org/10.1111 /j.1747-0080.2010.01496.

LSRO (1990). Core Indicators of Nutritional State for Difficult-to-sample Populations. Bethesda, Maryland. From https://www.faseb.org/ Portals/2/PDFs/LSRO_Legacy_Reports / 1990_ Core Indicators of Nutritional State for Difficult-to-sample Populations.pdf [Retrieved March 6 2017].

Md Hafizi A (2013). Financial literacy research on undergraduate students in Malaysia: current literature and research opportunities. Int $J$ Educ Res 1(11):1-12.

Meldrum LA \& Willows ND (2006). Food insecurity in university students receiving financial aid. Can J Diet Pract Res 67(6):43-46. https://doi. org/10.3148/67.1.2006.43

MOE Malaysia (2013). Indikator Pengajian Tinggi Malaysia. Ministry of Education Malaysia From https: / / mohe.gov.my/en/download/awam/ statistik/2013/76-indikator-pengajian-tinggimalaysia-2013/file [Retrieved March 6 2016]

Mohamad Fazli S \& MacDonald M (2010). Savings behavior and financial problems among college students: the role of financial literacy in Malaysia. Crosscultural Communication 6(3):P103-110. https://doi.org/10.3968/j. ccc. 1923670020100603.009

Mohamad Fazli S, Macdonald M, Jariah M \& Laily $P$ (2008). Financial behaviour and problems among college students in Malaysia: research and education implication. Consumer Interests Annual 54:166-170.

Norhasmah S, Zuroni MJ \& Marhana AR (2013). Implication of food insecurity among students receiving financial assistance in public institution of higher education. MAJCAFE 16(December):78-90
Nur Atiqah A, Norazmir M, Khairil Anuar M, Mohd Fahmi M \& Norazlanshah H (2015). Food security status: It's association with inflammatory marker and lipid profile among young adult. International Food Research Journal 22(5):1855-1863.

Nur Hafizah M, Muhammad Shahrim AK, Mohhidin O \& Hazrina G (2013). Relationships of socioeconomic level with eating behavior of traditional food among adolescents. Mediterr $J$ Soc Sci 4(11):13-20. https:/ / doi.org/10.5901/ mjss.2013.v4n11p13

OHCHR (1948). Universal Declaration of Human Rights. United Nations. https://www.ohchr. org/en/udhr/documents/udhr_translations / eng.pdf [Retrieved November 10 2019]

Pendergast FJ, Livingstone KM, Worsley A \& McNaughton SA (2016). Correlates of meal skipping in young adults: a systematic review. Int J Behav Nutr Phys Act 13(1):125. https:/ / doi.org/10.1186/s12966-016-0451-1

Rose D, Bodor J, Swalm C, Rice J, Farley T \& Hutchinson $P$ (2008). Deserts in New Orleans? illustrations of urban food acces and implications for policy. Vasa (February): 1-30. From http://medcontent.metapress.com/ index/A65RM03P4874243N.pdf [Retrieved November 10 2019]

Thanthida W (2010). Food Security in Thailand: Hunger in the Midst of Plenty. Georgetown University. Washington, DC.

USDA (2012). U.S. Adult Food Security Survey Module: Three-stage design, with screeners 2012(September):7. U.S. Department of Agriculture, Washington DC. https://www.ers. usda.gov/media/8279/ad2012.pdf

Wan Azdie MAB, Shahidah I, Suriati S \& Rozlin AR (2019). Prevalence and factors affecting food insecurity among university students in Pahang, Malaysia. Mal J Nutr 25(1):59-67.

WFP (2020). Zero hunger. World Food Programme. From https://www.wfp.org/zero-hunger [Retrieved January 25 2020]. 